\title{
Józef Puciłowski OP, Portrety imienne i bezimienne. Polscy dominikanie i bezpieka 1945-1989, Wydawnictwo Esprit, Kraków 2017, ss. 240.
}

W czasach Polski Ludowej Kościół znajdował się w kręgu szczególnego zainteresowania służb komunistycznych, ze względu na swoją antymarksistowską doktrynę i ogromny wpływ, jaki wywierał na polskie społeczeństwo, w przeważającej części katolickie. Z tego powodu polscy duchowni byli inwigilowani i namawiani do współpracy z organami specjalnych służb państwowych, a działania te były wymierzone także w osoby konsekrowane. Praca Józefa Puciłowskiego dotyczy tej właśnie tematyki w odniesieniu do polskich dominikanów i obejmuje lata 1945-1989. Autor recenzowanej książki to dominikanin i historyk Kościoła (doktorat z historii w 1977 r.), absolwent Uniwersytetu Wrocławskiego, który wypromował wiele prac magisterskich $\mathrm{z}$ historii Kościoła. Jest też cenionym kaznodzieją, znanym z bezpośredniości w wyrażaniu poglądów i ciętego języka.

Recenzowana książka zajmie zapewne poczesne miejsce w historiografii Kościoła czasów PRL, choć nie jest i zapewne nie będzie tak nośna jak chociażby głośna praca ks. T. Isakowicza-Zaleskiego ${ }^{1}$. Spośród prac, które ukazały się dotychczas, warto zwrócić uwagę na pracę zbiorową wydaną przez krakowski IPN pt. Komunistyczny aparat represji wobec Polskiej Prowincji Dominikanów, pod redakcją o. Marka Miławickiego i Michała Wenklara². Artykuły zawarte w wyżej cytowanej pracy są często przywoływane w recenzowanej książce.

Swoje wywody autor oparł na dosyć bogatej bibliografii, na którą składają się źródła archiwalne, w tym z Archiwum Polskiej Prowincji Dominikanów, źródła ze zbiorów IPN w Warszawie, Krakowie i we Wrocławiu, źródła drukowane, liczne opracowania a także „felietony, wspomnienia, wywiady, dyskusje”. Autor chętnie sięgał do prac magisterskich dotyczących historii Zakonu Kaznodziejskiego napisanych pod jego kierunkiem,

1 Zob. T. Isakowicz-Zaleski, Księża wobec bezpieki, Kraków 2007.

2 M. Miławicki, M. Wenklar (red.), Komunistyczny aparat represji wobec Polskiej Prowincji Dominikanów, Kraków 2015. 
przede wszystkim w czasach PRL. Obszernej bibliografii nie wtóruje jednak liczba przypisów, których w książce jest stosunkowo mało.

Spośród czasopism autor wykorzystał tylko pojedyncze numery periodyków takich jak „Tygodnik Powszechny”, „Więź”, „Znak” i kilka numerów dominikańskiej „Róży Duchownej”, przy czym zakres chronologiczny cytowanej publicystki obejmuje tylko okres Polski Ludowej, a odwołuje się ona głównie do wywiadów z ówczesnymi dominikanami. Zastanawiające jest to, czemu J. Puciłowski nie powołuje się na współczesną publicystykę, a przecież informacje o korelacjach bezpieki z polskimi duchownymi często w niej powracają. Być może autor odnosi się do przytoczonych czasopism jako przedstawiciel tzw. Kościoła otwartego, ponieważ właśnie do tego nurtu odwołują się te czasopisma i na ich łamach, zwłaszcza w okresie PRL, ukazywały się teksty odstające od oficjalnej linii nauczania Kościoła, choćby w kwestiach bioetycznych. Sam zresztą na łamach „Więzi” i „Tygodnika Powszechnego" publikuje. J. Puciłowski przyznaje wprost, że dominikańskie pismo „W drodze” było periodykiem innym niż „Znak” czy „Więź” (s. 111).

W pracy zamieszczono bardzo obszerny Wstęp i bardzo krótkie, bo mieszczące się zaledwie na jednej stronie maszynopisu (!) Zakończenie, w którym autor wyraził perspektywy do dalszych badań nad podjętą tematyką. We Wstępie - aż na 28 stronach - J. Puciłowski zarysował dzieje i sytuację Kościoła katolickiego w powojennej rzeczywistości, nie unikając wyrażania własnych opinii i dokonywania ocen, co należy uznać za istotny atut pracy. Nie znalazły się tam jednak elementy typowe dla wprowadzania do pracy naukowej z dziedziny historii, takie jak określenie celów pracy czy też pytań badawczych, dotychczasowy stan badań, przyjętej metodologii, uzasadnienia ram chronologicznych i tematycznych. Nie dowiemy się także, co nowego recenzowana praca wkłada do dotychczasowej historiografii, zwłaszcza w odniesieniu do przytaczanej już pracy zbiorowej pod redakcją M. Miławickiego i M. Wenklara. Zaledwie dziesięciostronicowy czwarty rozdział pt. „Motywy uwikłania się dominikanów w kontakty z aparatem PRL” wliczyłbym raczej do rozdziału pierwszego jako podrozdział.

Publikacja składa się z wykazu skrótów, podziękowań, wstępu, czterech zasadniczych rozdziałów, zakończenia, wykazu tabel, bibliografii i indeksu osobowego. W rozdziale pierwszym nakreślono sytuację zakonu dominikańskiego w komunistycznej rzeczywistości, biorąc pod uwagę przede wszystkim jego formację i wkład w rozwój inteligencji katolickiej. Rozdział drugi dotyczy duszpasterstwa młodzieży akademickiej w czasach PRL, gdzie dominikanie mieli wielkie zasługi głownie za sprawą znanej „Beczki”, funkcjonującej zresztą po dziś dzień. Trzeci rozdział, najobszerniejszy 
i najważniejszy w pracy, pod wymownym tytułem „Niezłomni i złamani”, koncentruje się na sylwetkach poszczególnych dominikanów, którzy pozostali nieugięci wobec aparatu represji, i tych, których udało się złamać i namówić do współpracy. Ci drudzy na ogół określani są pseudonimami i nie jest znana ich dokładna tożsamość. W czwartym rozdziale o. Puciłowski przedstawił motywy, jakimi kierowali się dominikanie, decydując się na współpracę z komunistycznymi służbami.

Służbom komunistycznym zależało na tym, aby zdyskredytować tych kapłanów, którzy w rzeczywisty sposób wpływali na politykę w diecezji czy też w zakonie. Wspomniani duchowni wywierali też wpływ na postawy osób świeckich związanych z Kościołem. Odbywało się to na zasadzie obopólnej korzyści - kapłani w zamian za współpracę mieli uławiane wyjazdy na Zachód, choćby w celach naukowych, jednak z takiej gratyfikacji byli wyłączeni bracia zakonni. Z uwagi na trudności związane z wyjazdami do krajów Europy Zachodniej w tamtym czasie niektórzy księża uginali się i byli skłonni przystać na te propozycje. W zasobach Instytutu Pamięci Narodowej autor odnalazł tylko jeden przypadek współpracy brata kooperatora z funkcjonariuszami bezpieki, choć - jak sam zaznacza - nie oznacza to wcale, że takich przypadków nie było więcej, a ten wspomniany był wyjątkowy, gdyż wiązał się z szantażem na tle obyczajowym w okresie stanu wojennego (s. 14-15). Niektórych polskich duchownych, w tym zakonników, przyciągało do komunistów też hasło równości wszystkich ludzi i emancypacji całej ludzkości. Było ono popularne zwłaszcza wśród tych, którzy pochodzili z wiejskiej biedoty. Ruchy lewicowe, w jakie angażowali się ich bracia z Zachodu, również ich intrygowały. Niektórzy podejmowali też współpracę z tajną policją komunistyczną, która rozciągała swoje wpływy na Kościół, także na zakony (s. 28). Szkoda, że autor nie zadał sobie trudu, by odpowiedzieć na pytanie, czy „lewicowe nowinki”, jakim ulegali duchowni na Zachodzie, były wśród nich popularne od dawna, czy też pojawiły się w Kościele dopiero po Soborze Watykańskim II - wraz z jego otwartością na świat.

O tym, jak wielkim autorytetem wśród Polaków cieszył się w tamtym czasie Kościół, świadczy fakt, że na tzw. Ziemiach Odzyskanych ludzie decydowali się osiedlić tylko pod warunkiem, że w ich miejscowości będzie rezydował także jakiś ksiądz. Autor podkreśla zasługi Kościoła w ,zakorzenieniu" się tam nowo przybyłych Polaków oraz w pracy duszpasterskiej wśród nich. Zasługi te stały się udziałem Kościoła dzięki decyzjom administracyjnym kard. Augusta Hlonda (s. 18-19). Z podobną estymą wypowiada się J. Puciłowski na temat kard. Stefana Wyszyńskiego, podkreślając jego zasługi dla obrony interesów Kościoła w tamtym czasie, a kierunek 
jego polityki autor określa jako „ofensywny” (s. 23). Przyczyniła się ona w największym stopniu do obalenia komunizmu w sposób pokojowy (s. 24). J. Puciłowski przypomina słowa papieża Jana Pawła II, który stwierdził, że „nie byłoby tego papieża, gdyby nie prymas...” (s. 25). Trudny charakter kardynała był też zdaniem autora przyczyną konfliktu z o. Krzysztofem Kasznicą, ówczesnym prowincjałem dominikanów.

Wśród motywów, którymi kierowali się polscy dominikanie podejmujący współpracę z komunistami, były szantaże związane ze sprawami obyczajowymi (związek z kobietą i homoseksualizm), pieniądze, karierowiczostwo, w tym ambicje na polu nauki, czemu miały służyć wyjazdy zagraniczne, będące pokłosiem także złej atmosfery panującej w klasztorach, niedostatek leków i odzieży, w których zaopatrzenie przełożeni czasem nie wyrażali zgody, a także niedojrzałość samych zakonników, pochodzących często z zacofanych środowisk (s. 199-207). Wyłania się tu obraz dominikanina głęboko uwikłanego w ludzkie słabości, stroniącego od chrześcijańskich ideałów, który popełniał liczne błędy. Przytoczony zostaje przykład jednego ze współpracowników bezpieki, który miał nakłonić swoją konkubinę do aborcji (s. 181). Wielu z nich odeszło z Zakonu Kaznodziejskiego jeszcze przed upadkiem komunizmu w Polsce. Nie jest to jednak postawa dominująca wśród polskich dominikanów w tamtym czasie, gdyż większość z nich odznaczała się szlachetnością życia i nie dała się uwikłać we współpracę ze specsłużbami, podobnie zresztą jak przeważająca część polskiego duchowieństwa.

Styl narracji J. Puciłowskiego, za sprawą jego lekkiego pióra, jest przyjemny w odbiorze dla czytelnika, a pracę czyta się szybko. Autor posługuje się czasem anachronicznymi w moim odczuciu pojęciami, takimi jak „Sowiety” (np. s. 20), „demoludy” (np. s. 21), popełnia też błędy wyrażeniowe (np. „po 123 latach rozbiorów”, powinno być: „,po 123 latach zaborów" - s. 77). W tekście pojawiają się nader często zawarte w nawiasie krótkie zwroty zakończone wykrzyknikiem wyrażające emocje autora. Dla przykładu: ,acz krytycznie!” (s. 120), „wydaje się, że był kompletnym daltonistą!” (s. 162), „nie mówiąc o kłamstwie!” (s. 171). Taki narracyjny protekcjonalizm rzutuje moim zdaniem negatywnie na naukowy walor pracy, choć zdaję sobie sprawę z tego, że autor ma własny styl prowadzenia narracji, korespondujący ze stylem jego kazuistyki, który sprawia, że lektura książki, mimo wszystko, jest czystą przyjemnością.

Szkoda, że autor nie konfrontuje ze sobą różnych źródeł historycznych, a brak przypisów na wielu stronach sprawia, że nie wiadomo z jakich źródeł korzysta o. Puciłowski, gdy przytacza konkretne informacje. Powoływanie się na wiedzę poza źródłową jest istotnym elementem pracy historyka. 
Recenzowana publikacja na pewno jest w stanie zaciekawić osoby interesujące się współczesną historią Kościoła i okresem PRL. Książka posiada imprimatur prowincjała Polskiej Prowincji Dominikanów, została zatem wydana za pełną wiedzą i zgodą Kościoła. Napisanie pracy na pewno kosztowało autora wiele czasu i wysiłku, a efekt zasługuje na pochwałę. Dopóki jednak, jak przyznaje autor, nazwiska „TW” pozostają nieujawnione, „drogi zakonu w latach 1945-1989 zahaczają o półprawdę!” (s. 210).

Przemysław Sołga 